\title{
Assessment of the Natural Landscape Changes Due to Cashew Plantations in the Department of Niakaramandougou (North of Côte d'Ivoire)
}

\author{
Souleymane Cisse*, Talnan Jean Honoré Coulibaly, Naga Coulibaly, Claude Alain Kouadio, \\ Houebagnon Saint Jean-Patrick Coulibaly, Sacré Regis Didi, Issa Camara
}

Laboratoire GeoSciences et Environnement (LGE), UFR Sciences et Gestion de Environnement (SGE), University of Nangui Abrogoua (UNA), Abidjan, Côte d'Ivoire

Email: *cissesouleymane111@gmail.com

How to cite this paper: Cisse, S., Coulibaly, T.J.H., Coulibaly, N., Kouadio, C.A., Coulibaly, H.S.J.-P., Didi, S.R. and Camara, I. (2021) Assessment of the Natural Landscape Changes Due to Cashew Plantations in the Department of Niakaramandougou (North of Côte d'Ivoire). Journal of Agricultural Chemistry and Environment, 10, 196-212. https://doi.org/10.4236/jacen.2021.102013

Received: March 5, 2021

Accepted: May 16, 2021

Published: May 19, 2021

Copyright $\odot 2021$ by author(s) and Scientific Research Publishing Inc. This work is licensed under the Creative Commons Attribution International License (CC BY 4.0).

http://creativecommons.org/licenses/by/4.0/

\begin{abstract}
In the past twenty years, Côte d'Ivoire has risen from being an insignificant producer of raw cashew nuts to becoming the world's largest producer. A rapid increase of cashew plantations has significantly changed the natural landscape in the North part of Côte d'Ivoire. This study was conducted in the department of Niakaramadougou to assess the natural landscape change due to cashew plantations from 1989 to 2017. Satellite image data were used in order to evaluate land use land cover (LULC) change. The maximum likelihood pixel-based on classification method was used to analyze the spatiotemporal LULC dynamics for the years 1989, 2000, and 2017. The results showed an increase in cashew culture by $20.68 \%$ between 1989 and 2017 to the detriment of the savannah. Thus, the land devoted to old fallows or to other crops such as rice, maize, yams, peanuts, sorghum) is decreasing and the natural vegetation is becoming more and more fragmented, with consequences that are not yet known. This surely contributes to the reduction of plant diversity.
\end{abstract}

\section{Keywords}

LULC, Cashew Nut, Remote Sensing, Niakaramadougou Department, Côte d'Ivoire

\section{Introduction}

In the recent decade, cashew plantations have increased considerably in the world. In terms of surface, it is estimated at $75,000 \mathrm{~km}^{2}$ in 32 countries worldwide [1]. Global cashew nut production was estimated at 3,341,000 tons in 2015 [2]. West 
African countries in general and Côte d'Ivoire, in particular, know this rapid development of cashew plantations. The total area is estimated at $5000 \mathrm{~km}^{2}$ in 2006 and increased to reach $13,500 \mathrm{~km}^{2}$ in 2018 [2]. Thus, the production increased from 235.000 tons in 2006 to over 738.000 tons in 2018. This increase in production has made Côte d'Ivoire the world's largest producer of raw cashew, in front of India and Vietnam, and the world's largest exporter of raw cashew [3]. This success can be explained by the increase in Asian demand for cashew nuts, which has provided an important economic incentive [4]. The rapid extension of cashew plantations is beginning to raise some questions, which will impact the natural landscape. The changes in land use due to cashew plantation are evident, particularly in central and northern parts of Côte d'Ivoire where the production is intense. The savannah and forest in these areas are almost all being converted into cashew plantations. Several research works have been carried out on cashew nuts [5] [6] [7] [8]. These studies were generally focused on good cultural practices for better optimization of cashew nut production. Our case study focused on the impact of cashew plantations on the natural landscape. This study aims to assess LULC change due to cashew plantations in the department of Niakaramandougou. The paper is structured as follows: "Material and methods" section presents the material and the methods used in this study while "Results and discussion" section show the results and the overall discussion. The conclusion is presented in "Conclusion" section.

\section{Material and Methods}

\subsection{Study Area}

The study area (Figure 1) is. located in the North part of Côte d'Ivoire, precisely in the Hambol region about 500 kilometers from the economic capital Abidjan between Latitudes of 210,000 and 300,000 $\mathrm{m}$ and Longitudes of 930,000 and $102,000 \mathrm{~m}$ in geographic coordinate system (WGS 84 , zone $30 \mathrm{~N}$ ). It is estimated at $6602.08 \mathrm{~km}^{2}$ of area. The climate is tropical with two distinct seasons. Specifically, it is Sudanese in the north of the department and Baoulean in the south. The rainy season is from mid-April to October and the dry season from November to mid-April, dominated by the harmattan, a hot and dry wind. The average annual rainfall is ranging from 1000 to $1600 \mathrm{~mm}$. The average annual temperature is $26^{\circ} \mathrm{C}$. [9]. The relief of the Niakaramadougou department is rather monotonous, almost horizontal with very little marked shapes. Niakaramandougou vegetation is in the Sudanese domain. Vegetation is dominated by wooded savannah, although it is more shrubby and grassy in its northern part. There are dry forests in various places and galleries forest along rivers in the relatively better watered southern part [10]. According to [11] forest cover has decreased in the Sudanese domain from $69.94 \mathrm{~km}^{2}$ in 1986 to $55.13 \mathrm{~km}^{2}$ in 2000 and $52.77 \mathrm{~km}^{2}$ in 2015 .

\subsection{Material}

The availability of Landsat images from the sensor series (TM, ETM+ and OLI) 

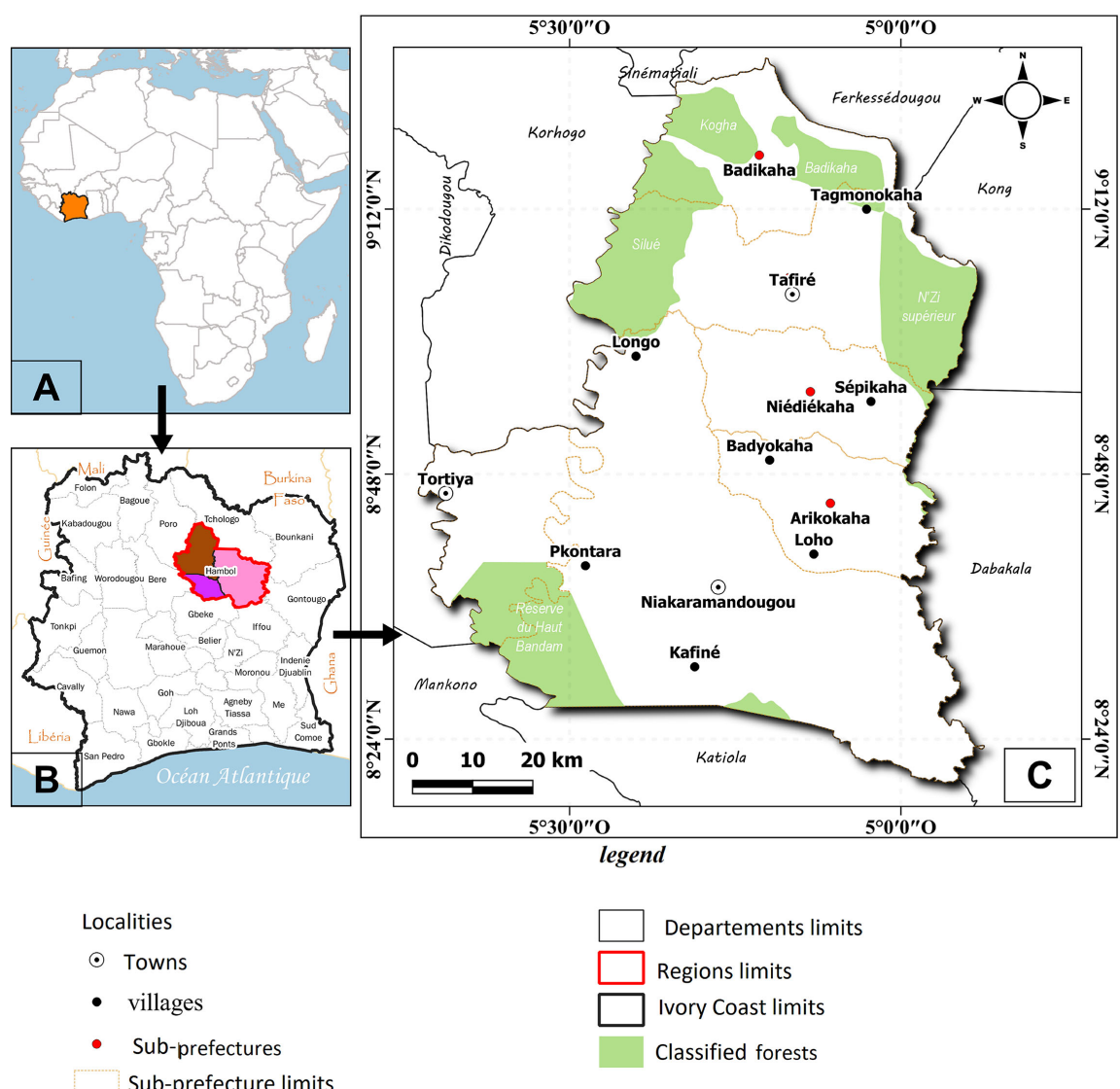

Figure 1. Presentation of the study area.

were chosen for this study. In fact, this sensor provides the longest free and available record that allows the study of recurrent phenomena such as flood return periods [12]. Moreover, these resolutions (spatial, spectral and temporal) meet the requirements of thematic monitoring and changes in terrestrial components [13]. The LANDSAT images used in this study are all from the dry period. The selected images are three TM and ETM+ and OLI (scene 197; 54) acquired on 29-02-1989, 16-02-2000 and 28-01-2017 respectively. They were provided by the United (USGS), with a spatial resolution of $30 \mathrm{~m}$. The data from the field campaign are essentially composed of geographical coordinates and land cover photographs of the study area.

\subsection{Methods}

\subsubsection{Radiometric and Atmospheric Correction}

Dark Object Subtraction (DOS) has been applied to our images to reduce atmospheric effects. The Dark Object Subtraction (DOS) method is an imagebased technique to cancel out the haze component caused by additive scattering from remote sensing data [14]. This method is found to be data dependent and well accepted by the geospatial community to correct light scattering in remote sensing data [15]. Also the radiometric corrections applied, are operations that consisted of correcting reflectance and radiance data (absorption and scattering 
of gases, aerosols and dust) [16]. Both of these correction methods were automatically applied to the images using the Radiometric calibration and Dark substraction modules of the ENVI software. Radiance and reflectance are respectively calculated through the following equation:

Radiance in $\mathrm{W} /\left(\mathrm{m}^{2} \times \mathrm{sr} \times \mu \mathrm{m}\right)$

$$
L_{\lambda}=\text { Gain } * \text { Pixel value }+ \text { Off set }
$$

Reflectance

$$
\rho_{\lambda}=\frac{\pi L_{\lambda} d^{2}}{E S U N_{\lambda} \sin \theta}
$$

$L_{\lambda}$ : Radiance in unit of $\mathrm{W} /\left(\mathrm{m}^{2} \times \mathrm{sr} \times \mu \mathrm{m}\right)$;

$d$ : Earth-Sun distance, in astronomical units;

$E S U N_{\lambda}$ : solar irradiation in units of $\mathrm{W} /\left(\mathrm{m}^{2 *} \mu \mathrm{m}\right)$;

$\theta:$ elevation of the sun in degrees.

\subsubsection{Color Composites and Cashew Tree Discrimination}

Color composites consists of assigning to each primary colour (red, green and blue) three spectral bands of a satellite sensor [17]. Following several combinations, the colour composition 4-3-2 was chosen for the TM and ETM+, then 5-4-3 was chosen for the OLI image [18]. These two colours composites allowed us to better discriminate Cashew trees among land cover types. As for cashew tree detection, it should be noted that the period in which landsat images were recorded (December, January and February) are period where cashew trees are well discriminated as a crop in the department. However rice, corn and yam, etc., are cultivated respectively from March to June. Besides cashew tree reflects differently from other crops and shrubs, which makes it easier to discriminate it on a Landsat image once processed. To validate, four samples of each class have been chosen in order to be confirmed on the field.

\subsubsection{Image Classification and Validation}

The maximum likelihood algorithm is the one used to perform this classification. This method calculates the probability that a pixel belongs to a given class. The pixel will be assigned to the class for which the probability is the highest. However, if this probability does not reach the expected threshold, the pixel is classified as "unknown" [19]. A statistical test based on the realization of the confusion matrix made it possible to evaluate each of the classified images. This test gives the cartographic accuracy displayed for each class, the overall cartographic accuracy and the value of the kappa coefficient. This test was executed automatically thanks to the Confusion Matrix Using Ground Truth Image module. The Kappa coefficient $(k)$ and the overall accuracy $(O A)$ are calculated according to the following equation:

$$
k=\frac{N \sum_{i=1}^{n} m_{i, i}-\sum_{i=1}^{n}\left(G_{i} C_{i}\right)}{N^{2}-\sum_{i=1}^{n}\left(G_{i} C_{i}\right)}
$$


- $i$ is the class number.

- $N$ is the total number of classified pixels that are compared to the field truth.

- $m_{i, i}$ is the number of pixels belonging to the ground truth class $i$, which have also been classified with a class $i$ (i.e. values found along the diagonal of the confusion matrix).

- $C_{i}$ is the total number of classified pixels belonging to class $i$.

- $G_{i}$ is the total number of ground truth pixels belonging to class $i$.

$$
O A=\frac{\text { sum of the different well }- \text { classified pixels }}{\text { total number of sampled pixels }} * 100
$$

\subsubsection{Analysis of Land Use Dynamics}

Post-classification comparison method has been used to analyse land use land cover dynamic. A matrixes for detecting changes resulting from the comparison between pixels of two classifications at two different dates is produced [20]. Transition matrix are developed to describe changes in land use during a given time period [21]. Class areas from one year to the next were calculated using the vector format of the classified image using the "field calculator" module of Qgis software. From this, the global rate of change $(G c)$ and the annual average rate of spatial expansion $(R c)$ and the transition matrix were calculated.

$$
R c=\left[\left(\frac{S_{2}}{S_{1}}\right)^{\frac{1}{t}}-1\right] * 100
$$

$T c=$ rate of change (\%); $S_{1}=$ area of the class at date $t_{1} ; S_{2}=$ area of the class at date $t_{2}\left(t_{2}>t_{1}\right) ; t=$ number of years between the two dates.

$$
G c=\left(\frac{D_{s}}{S_{t}}\right) * 100
$$

$D_{s}$ : variation in area of a land-use unit between $t_{1}$ and $t_{2} ; S_{i}$ : total area of all units.

Table 1 summarizes the method for calculating the transition matrix.

Table 1. Calculating of a transition matrix [22].

\begin{tabular}{ccccc}
\hline \multicolumn{5}{c}{ Category $\mathrm{j}$ at time $\mathrm{t} 1$} \\
\hline Category i at time t0 & Category $\mathrm{i} 1(\mathrm{j}=1)$ & Category $\mathrm{i} 1(\mathrm{j}=1)$ & category $\mathrm{i} 1(\mathrm{j}=1)$ & Sum of the Ejt1 of the columns \\
\hline Category i 1 $(\mathrm{i}=1)$ & $\mathrm{a}(1.1)$ & $\mathrm{a}(1.2)$ & $\mathrm{a}(1.3)$ & $\sum \mathrm{a}(1 . \mathrm{j}), \mathrm{j}=1 . \mathrm{n}$ \\
Category $\mathrm{i}$ 1 $(\mathrm{i}=2)$ & $\mathrm{a}(2.1)$ & $\mathrm{a}(2.2)$ & $\mathrm{a}(2.3)$ & $\sum \mathrm{a}(2 . \mathrm{j}), \mathrm{j}=1 . \mathrm{n}$ \\
Category i 1 $(\mathrm{i}=3)$ & $\mathrm{a}(3.1)$ & $\mathrm{a}(3.2)$ & $\mathrm{a}(3.3)$ & $\sum \mathrm{a}(3 . \mathrm{j}), \mathrm{j}=1 . \mathrm{n}$ \\
Sum of the Ejt1 of the columns & $\sum \mathrm{a}(\mathrm{i} .1), \mathrm{i}=1 . \mathrm{m}$ & $\sum \mathrm{a}(\mathrm{i} .2), \mathrm{i}=1 . \mathrm{m}$ & $\sum \mathrm{a}(\mathrm{i} .3), \mathrm{i}=1 . \mathrm{m}$ & $\sum \sum \mathrm{a}(\mathrm{i} .3), \mathrm{j}=1 . \mathrm{m}$ \\
\hline
\end{tabular}

\section{Results}

\subsection{Supervised Classification and Evaluation}

Seven LULC classes were identified in this study. It is: Cashew Plantations (CP), 
Light Forests (LF), Shrubs(S), Herbaceous Savannas (HS), Bare Floors/Habitat $(\mathrm{BF} / \mathrm{H})$, Water (E) and burns (B) find the description in (Table 2) bellow.

The evolution of LULC from 1989 to 2017 and the percentage are presented in Table 3.

Tables 4-6 present the confusion matrix after classification. The overall mapping accuracies and the respective Kappa index at the end of the classification of the different images are satisfactory. However, confusion exists between some classes following the classification of the images. These matrices show global map accuracies of $96.16 \%$ for the 1989 Landsat 5 TM image, $96.07 \%$ for the 2000 Landsat 7 ETM+ and $92.82 \%$ for the 2017 Landsat 8 OLI image. The values in bold diagonal (Tables 4-6) correspond for each land cover type to the well-ranked pixel rates. The different off-diagonal rates reflect the rates of misclassified pixels, i.e. pixels that have been assigned to a class to which they do not belong. The latter are usually the result of spectral confusion between the different classes.

Table 2. Land use/land cover classification scheme.

\begin{tabular}{|c|c|}
\hline LULC Categories & Description \\
\hline Cashew Plantations & Cashew nut plantation. \\
\hline Light Forests & It is a tree formation with elements spaced far enough apart for the ground to receive more light than shade. \\
\hline Shrubs & $\begin{array}{l}\text { Is a small- to medium-sized perennial woody plant. Unlike herbaceous plants, shrubs have persistent woody stems above } \\
\text { the ground... They are distinguished from trees by their multiple stems and shorter height, less than } 6 \mathrm{~m}-10 \mathrm{~m} \text {. }\end{array}$ \\
\hline Herbaceous Savannas & $\begin{array}{l}\text { Grassy formation consisting of a mat of tall grasses measuring, at the end of the growing season, at least } 80 \mathrm{~cm} \text { in height, } \\
\text { with flat leaves arranged at the base or on the culms, smaller grasses and herbaceous plants. }\end{array}$ \\
\hline Water & These are the permanent watercourses. \\
\hline Bare Floors/Habitat & $\begin{array}{l}\text { Urbanized areas and roads as well as land covered by buildings and other man-made structures but also empty land } \\
\text { without vegetation. }\end{array}$ \\
\hline Burns & These are the areas that have been burned. \\
\hline
\end{tabular}

Table 3. Confusion matrix of study area land cover classification of 1989, 2000 and 2017.

\begin{tabular}{|c|c|c|c|c|c|c|}
\hline \multirow[b]{2}{*}{ LULC Class $\left(\mathrm{km}^{2}\right)$} & \multirow[b]{2}{*}{1989} & \multirow[b]{2}{*}{2000} & \multirow[b]{2}{*}{2017} & \multicolumn{3}{|c|}{ Area coverage $(\%)$} \\
\hline & & & & 1989 & 2000 & 2017 \\
\hline $\mathrm{CP}$ & 127.68 & 952.85 & 1493.05 & 1.93 & 14.43 & 22.61 \\
\hline LF & 132 & 306.44 & 200.47 & 1.99 & 4.64 & 3.03 \\
\hline $\mathrm{S}$ & 1351.47 & 207.38 & 200.79 & 20.47 & 3.14 & 3.04 \\
\hline HS & 3618.63 & 4366.76 & 3928.97 & 54.81 & 66.14 & 59.51 \\
\hline W & 7.38 & 8.09 & 8.97 & 0.11 & 0.12 & 0.13 \\
\hline $\mathrm{BF} / \mathrm{H}$ & 1142.06 & 638.7 & 665.38 & 17.29 & 9.67 & 10.07 \\
\hline B & 222.83 & 121.82 & 104.41 & 3.375 & 1.84 & 1.58 \\
\hline
\end{tabular}


Table 4. Confusion matrix for 1989 classification.

\begin{tabular}{cccccccc}
\hline Classes (\%) & CP & LF & S & W & HS & BF/H & B \\
\hline CP & $\mathbf{7 3 . 8 9}$ & 0 & 9.89 & 0 & 0 & 0 & 0 \\
LF & 0 & 96.68 & 1.49 & 0 & 0 & 0 & 0.13 \\
S & 26.11 & 3.32 & $\mathbf{8 8 . 6 1}$ & 0 & 0 & 0 & 0 \\
W & 0 & 0 & 0 & 99.74 & 0 & 0 & 0.26 \\
HS & 0 & 0 & 0 & 0 & 95.42 & 0 & 0 \\
BF/H & 0 & 0 & 0 & 0 & 0.68 & 0 & 99.61 \\
B & 0 & 0 & 0 & 0.26 & 100 & 100 & 100 \\
Tolal & 100 & 100 & 100 & 100 & & & 0 \\
\hline
\end{tabular}

Overall Occuracy: 96.16\%; Kappa Coefficient: 0.95.

Table 5. Confusion matrix for 2000 classification.

\begin{tabular}{|c|c|c|c|c|c|c|c|}
\hline Classes (\%) & $\mathrm{CP}$ & LF & $S$ & HS & W & $\mathrm{BF} / \mathrm{H}$ & B \\
\hline $\mathrm{CP}$ & 96.5 & 0.3 & 0.32 & 3.9 & 0 & 0 & 0 \\
\hline LF & 0.3 & 98.15 & 0.03 & 0 & 0 & 0 & 0 \\
\hline$S$ & 1.65 & 1.68 & 99.65 & 0 & 0 & 0 & 0 \\
\hline HS & 1.31 & 0.14 & 0 & 89.87 & 0.18 & 0.06 & 0 \\
\hline $\mathrm{W}$ & 0 & 0 & 0 & 0 & 99.82 & 0 & 0 \\
\hline $\mathrm{BF} / \mathrm{H}$ & 0.25 & 0 & 0 & 6.4 & 0 & 99.94 & 0.17 \\
\hline B & 0 & 0 & 0 & 0.64 & 0 & 0 & 99.83 \\
\hline Total & 100 & 100 & 100 & 1000 & 100 & 100 & 100 \\
\hline
\end{tabular}

Overall Occuracy: 96.07\%; Kappa Coefficient: 0.95.

Table 6. Confusion matrix for 2017 classification.

\begin{tabular}{cccccccc}
\hline Classes (\%) & PA & FC & SB & SH & E & H/SN & B \\
\hline PA & $\mathbf{8 5 . 4 9}$ & 0.17 & 0.45 & 0 & 0 & 0 & 0 \\
FC & 7.27 & $\mathbf{8 8 . 4 9}$ & 0.45 & 0 & 0 & 0 & 0 \\
SB & 6.81 & 11.33 & $\mathbf{9 9}$ & 0 & 0 & 0 & 0.89 \\
SH & 0 & 0 & 10 & 94.96 & 0 & 0 & 0 \\
E & 0 & 0 & 0 & 0 & 99.72 & 0 & 0 \\
H/SN & 0.43 & 0 & 0 & 2.69 & 0.11 & 0 \\
B & 0 & 0 & 0 & 2.32 & 0 & 100 & 99.06 \\
Total & 100 & 100 & 100 & 100 & 100 & 100 \\
\hline
\end{tabular}

Overall Occuracy: 92.83\%; Kappa Coefficient: 0.91 .

The confusion matrix (Table 4) shows a good classification of shrubs image. However, some confusion has occurred. The most important of these confusions were observed between cashew plantations and wooded savannas, i.e. $26 \%$ of confusion However, the best cartographic accuracy rates were for the Bare Floors/Habitat (100\%), water (99.68\%) and burns land (99.61\%) classes.

In Table 5, there is very little spectral confusion between classes in general. Thus, the high confusions is observed between Bare Floors/Habitat classes and 
herbaceous savannas, classes i.e. $6 \%$ of confusion.

Table 6, like the others, shows us a good discrimination between the different land-use classes in the 2017 image. The best distinctions can be observed at the level of water classes (99. 72\%), Bare Floors/Habitat (99. 11\%) and burns (99. $06 \%)$.

\subsection{Analysis of Land Use Change between 1989 and 2000}

The results for the Landsat images classification to 1989 and 2000 are shown in Figure 2.

The analysis of these maps shows the dynamics of the land cover classes between these two observation dates. We find that almost all classes observed have changes. They have either increased or decreased in area (Figure 3 and Table 7).

This table above indicates Global rate of change values. first of all, shrubs, bare floors/habitat and burns land have decreased to respectively reach $1144.09 \mathrm{~km}^{2}$ (17.32\%), $503.36 \mathrm{~km}^{2}(7.62 \%)$ and $101.01 \mathrm{~km}^{2}(1.52 \%)$ of their initial area, i.e. that of 1989. and, they have been an increase in cashew culture area, light forests and herbaceous savannas, which have gained $825.17 \mathrm{~km}^{2}$ (12.49\%), $174.45 \mathrm{~km}^{2}$ (2.64\%) and $748.13 \mathrm{~km}^{2}(11.33 \%)$ respectively in eleven years. Table 7 shows the global change rate of the classes which, decreases to17.32\%, 7.62\% and $1.52 \%$ respectively for wooded savannas, bare floors/habitat and burns areas. There is also a global increase of $12.49 \% ; 2.64 \%$ and $11.33 \%$ respectively for cashew culture, light forests and herbaceous savannas in the study area. For further analysis of the changes between years, the transition matrix was carried out (Table 8).
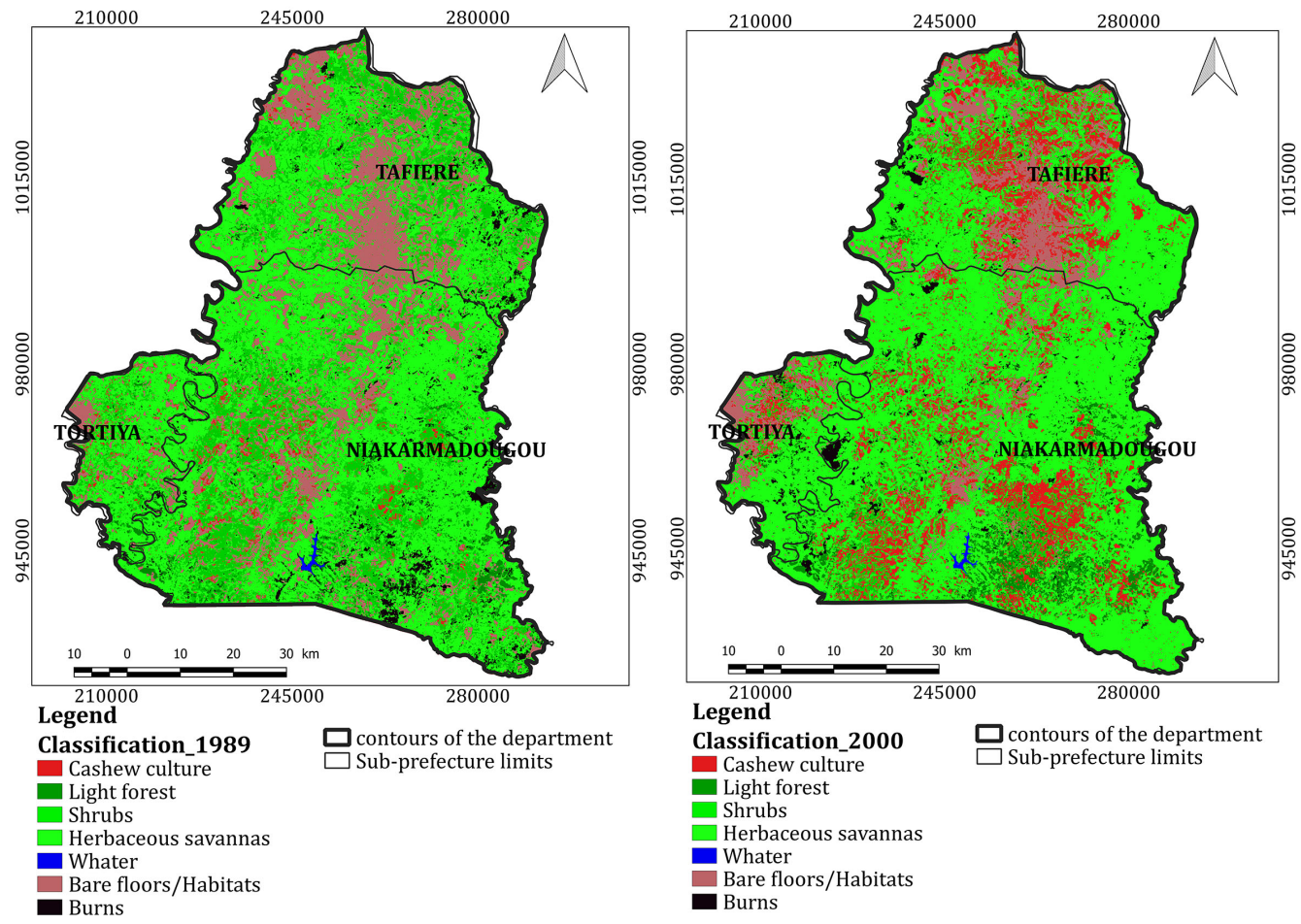

Figure 2. Land cover classification of the 1989 and 2000 images. 


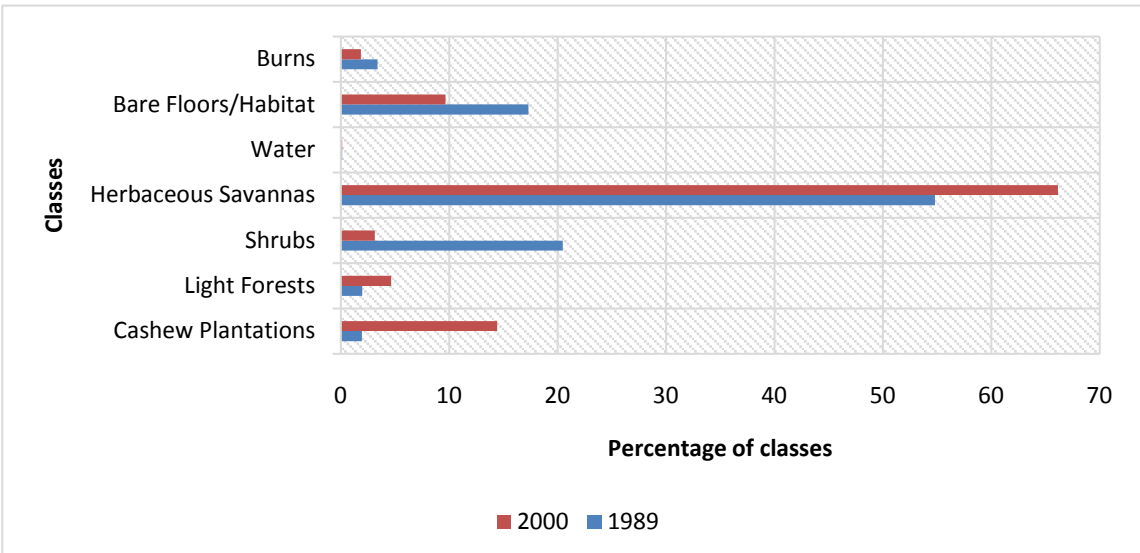

Figure 3. land use land cover change from 1989 to 2000.

Table 7. Land use class change rate between 1989 and 2000.

\begin{tabular}{ccc}
\hline Classes & $\mathrm{Gc}\left(\mathrm{km}^{2}\right)$ & $\mathrm{Gc}(\%)$ \\
\hline CP & 825.17 & 12.49 \\
LF & 174.45 & 2.64 \\
S & -1144.09 & -17.32 \\
HS & 748.13 & 11.33 \\
W & 0.71 & 0.01 \\
BF/H & -503.36 & -7.62 \\
B & -101.01 & -1.52 \\
\hline
\end{tabular}

Table 8. Land use class change rate between 1989 and 2000.

\begin{tabular}{ccccccccc}
\hline Classes (ha) & CP & LF & S & HS & W & BF/H & B & Total \\
\hline CP & 55.27 & 7.12 & 494.2 & 257.58 & 0 & 125.36 & 13.29 & 952.85 \\
LF & 3.61 & 74.83 & 114.86 & 70.24 & 0 & 12.68 & 30.17 & 306.44 \\
S & 5.71 & 19.73 & 158.6 & 15.17 & 0 & 2.67 & 5.48 & 207.38 \\
HS & 51.39 & 28.12 & 528.26 & 2945.16 & 0.23 & 650.97 & 162.5 & 4366.76 \\
W & 0 & 0 & 0 & 0 & 7.14 & 0.02 & 0.90 & 8.09 \\
BF/H & 10.44 & 0.47 & 44.99 & 244.74 & 0 & 333.45 & 4.59 & 638.70 \\
B & 1.23 & 1.69 & 10.51 & 85.69 & 0 & 16.8 & 5.88 & 121.82 \\
Total & 127.68 & 132 & 1351.47 & 3618.63 & 7.38 & 1142.06 & 222.83 & \\
\hline
\end{tabular}

This table shows that from 1989 to 2000 , the shrubs decrease to reach 1144.09 $\mathrm{km}^{2}, 1351.47 \mathrm{~km}^{2}$ of land occupied by shrubs in $1989,158.6 \mathrm{~km}^{2}$ remained unchanged; $494.2 \mathrm{~km}^{2}$ were transformed into cashew plantations, and $528.26 \mathrm{~km}^{2}$ were transformed into herbaceous savannas. Bare floors/habitat retained $33345.24 \mathrm{~km}^{2}$ while $808.52 \mathrm{~km}^{2}$ changed categories. Cashew plantation and herbaceous savannas classe are significantly changed. Cashew, light forests and herbaceous savannas retained $55.27 \mathrm{~km}^{2}, 74.83 \mathrm{~km}^{2}$ and $2945.16 \mathrm{~km}^{2}$ of their estimated areas of $127.68 \mathrm{~km}^{2}, 132 \mathrm{~km}^{2}$ and $3618.63 \mathrm{~km}^{2}$ respectively. 


\subsection{Analysis of Land Use Change between 2000 and 2017}

The results for the Landsat images classification to 2000 and 2017 are shown in Figure 4.

Figure 5 and Table 9 show the evolution of the areas of the different land-use types and the rates of change between 2000 and 2017

During this period, cashew plantations area increased to reach $540.19 \mathrm{~km}^{2}$, i.e. $8.8 \%$ of the total area of the department. All this with a global rate of spatial expansion of $8.18 \%$. The savanna area declined and lost $444.37 \mathrm{~km}^{2}$, i.e. $6.72 \%$ less than in 2000. A global decrease of $0.09 \%$ and $6.63 \%$ respectively for wooded and herbaceous savannas can also be noted at their level. As for bare floors/habitats, the surface area of water bodies and burns areas remained almost stable between these two observation dates. The changes in land use classes between these two years are revealed by the transition matrix presented in Table 10 below.

Examination of the transition matrix reveals that $164.65 \mathrm{~km}^{2}$ of the light forest area estimated at $306.44 \mathrm{~km}^{2}$ in 2000 remained in this category in 2017. 141.79 $\mathrm{km}^{2}$ have converted to other classes including $31.77 \mathrm{~km} 2$ to cashew culture, 11.8 $\mathrm{km}^{2}$ to wooded savanna and $98 \mathrm{~km}^{2}$ to herbaceous savanna. The wooded and herbaceous savannas retained $175.68 \mathrm{~km}^{2}$ and $3671.51 \mathrm{~km}^{2}$ of their total area respectively. They gave up $19.17 \mathrm{~km}^{2}$ and $451.44 \mathrm{~km}^{2}$ respectively, i.e. a total of 47061.54 ha to cashew plantations. As for the waterways, bare floors/ habitats and burns they have preserved $8.0829 \mathrm{~km}^{2}, 457.62 \mathrm{~km}^{2}$ and $98.4 \mathrm{~km}^{2}$ respectively.

Table 9. Land use class change rate between 2000 and 2017.

\begin{tabular}{ccc}
\hline Classes & $\mathrm{Gc}\left(\mathrm{km}^{2}\right)$ & $\mathrm{Gc}(\%)$ \\
\hline CP & 540.19 & 8.18 \\
LF & -105.97 & -1.6 \\
S & -6.59 & -0.09 \\
HS & -437.78 & -6.63 \\
W & 0.88 & 0.01 \\
BF/H & 26.69 & 0.4 \\
B & -17.42 & -0.26 \\
\hline
\end{tabular}

Table 10. Land use class change rate between 2000 and 2017.

\begin{tabular}{ccccccccc}
\hline Classes $\left(\mathrm{km}^{2}\right)$ & CP & LF & S & HS & W & BF/H & B & Total \\
\hline CP & 892.44 & 31.77 & 19.17 & 451.44 & 0 & 98.21 & 0 & 1493.05 \\
LF & 0.35 & 164.65 & 3.49 & 31.17 & 0 & 0.01 & 0.77 & 200.47 \\
S & 10.76 & 11.8 & 175.68 & 2.19 & 0 & 0.32 & 0.01 & 200.79 \\
HS & 45.67 & 98 & 8.57 & 3671.51 & 0 & 82.51 & 22.6 & 3928.97 \\
W & 0 & 0 & 0 & 0.89 & 8.08 & 0 & 0 & 8.97 \\
BF/H & 3.58 & 0.01 & 0.43 & 203.33 & 0 & 457.62 & 0 & 665.38 \\
B & 0 & 0.12 & 0 & 5.86 & 0 & 0 & 98.4 & 104.41 \\
Total & 952.85 & 306.44 & 207.38 & 4366.75 & 8.09 & 638.70 & 121.82 &
\end{tabular}



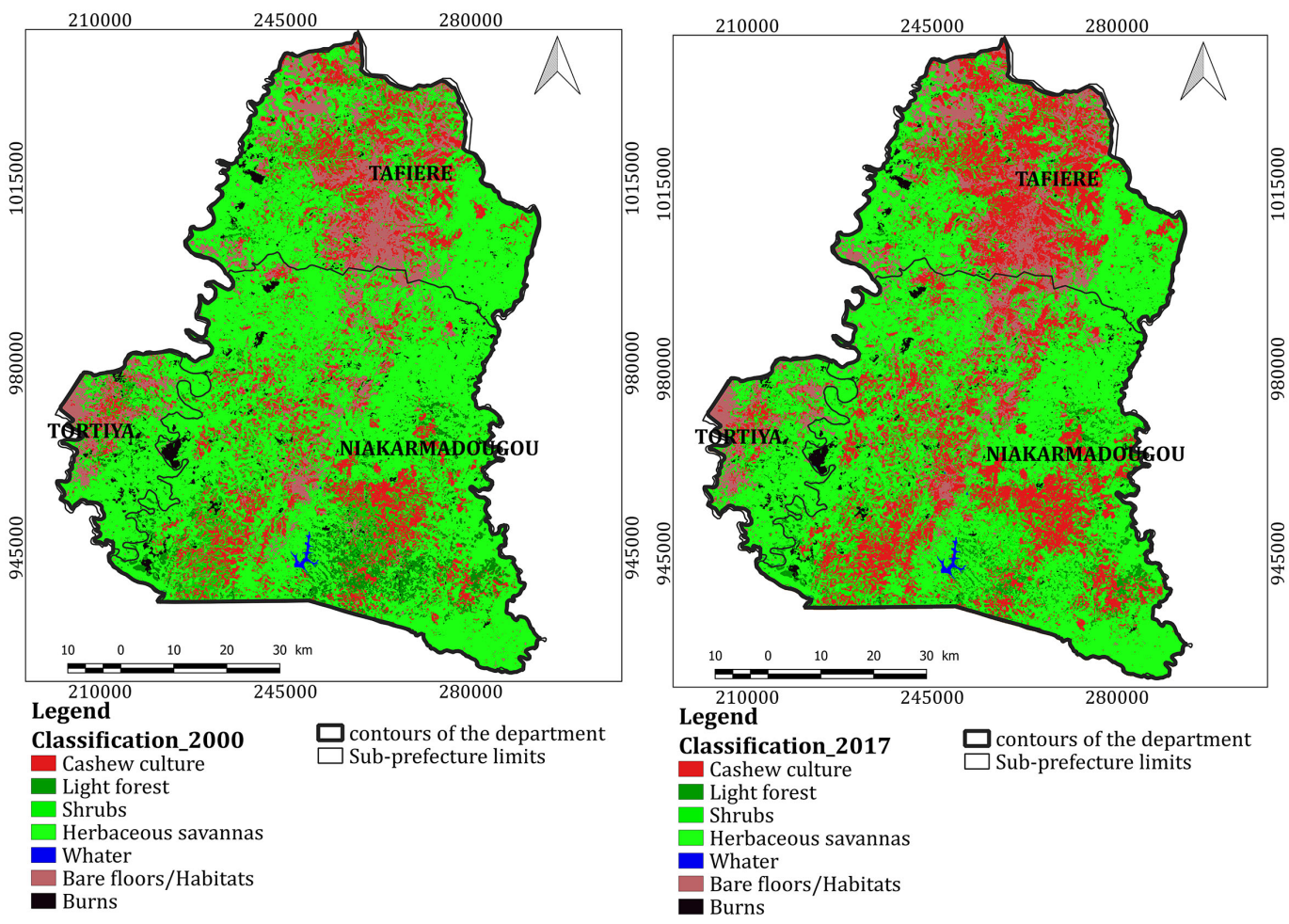

Figure 4. Land cover classification of the 2000 and 2017 images.

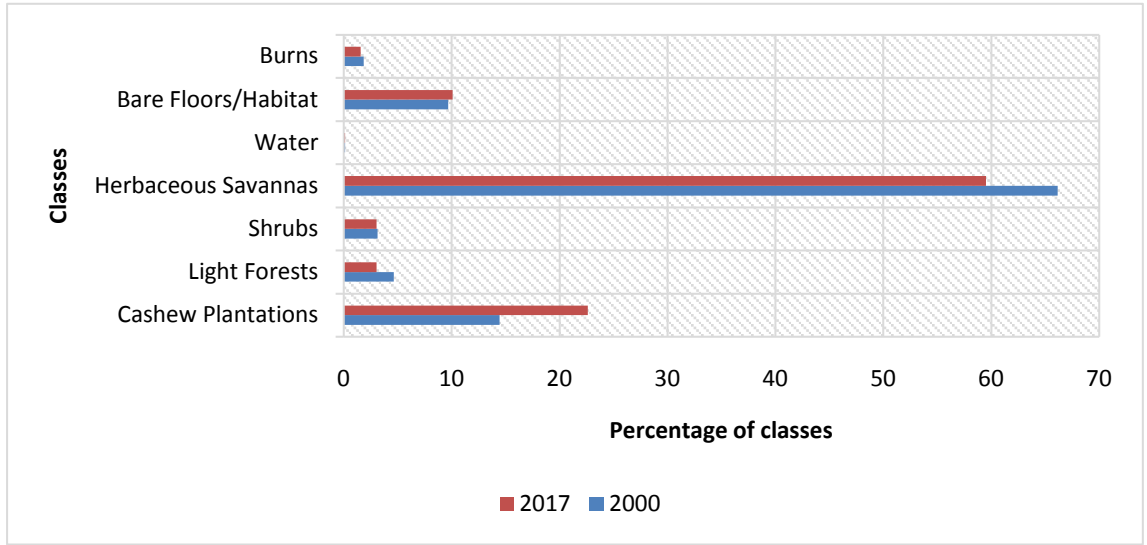

Figure 5. Changing in land use class areas from 2000 to 2017.

\subsection{Analysis of Land Use Change between 1989 and 2017}

The analysis of land use/Land cover change highlights that the change occurred between the different periods: 1989-2017 (Figure 6 and Figure 7). In addition, and the overall rate of change were calculated (Table 11).

Between 1989 and 2017, we noticed an increase in cashew culture area, and reached $1365.36 \mathrm{~km}^{2}$ more of the total area of the study area with an overall rate of change of $20.68 \%$. The savannas formations (wooded and herbaceous savannas) globally regressed to 84033 ha from 1989 to 2017 with an overall change rate of $12.42 \%$. Bare floors/habitats also decrease with an overall change of 7.21\%. Light changes of forests and streamflow were observed. The transition 
matrix was carried out in order to have more information on the observed changes (Table 12).

Savannah formation were estimat to 497,011 ha in 1989 , only 288,643 ha remains. $1145.2059 \mathrm{~km}^{2}$ have been coverted into cashew culture, $106.7058 \mathrm{~km}^{2}$ into ligth forest and $334.9053 \mathrm{~km}^{2}$ into habitat/bare floors. Cashew culture espansion is made at the expense of savannah $\left(1145.2059 \mathrm{~km}^{2}\right)$, ligth forest $\left(11.0277 \mathrm{~km}^{2}\right)$ bare floors/habitats $\left(246.6036 \mathrm{~km}^{2}\right)$ and burns areas $\left(19.7181 \mathrm{~km}^{2}\right)$. A shrubs are converted to lgth forest $\left(80.8515 \mathrm{~km}^{2}\right)$ Bare floors/habitats and burns area are also coverted to another LULC class.
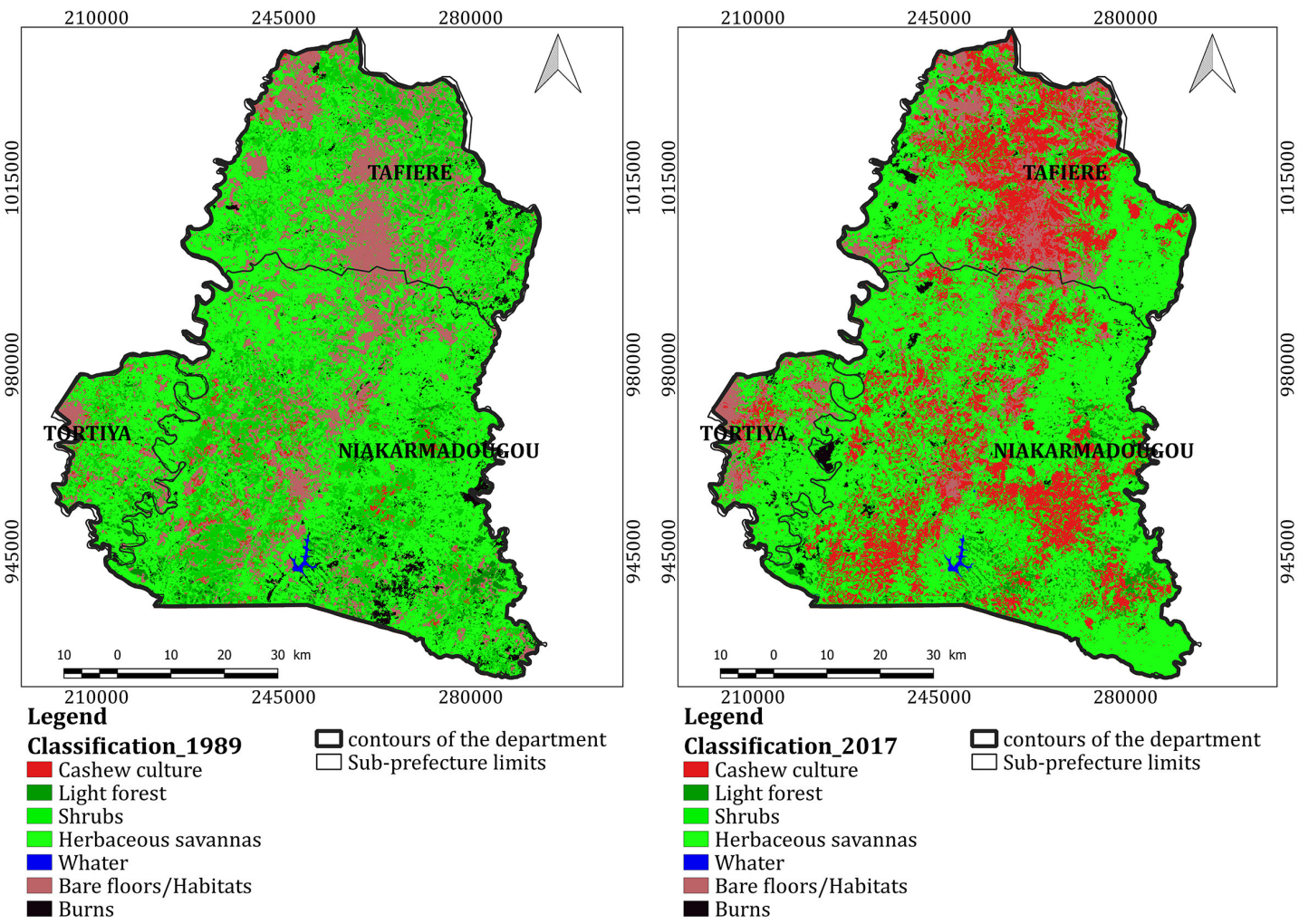

Figure 6. Land cover classification of the 1989 and 2017 images.

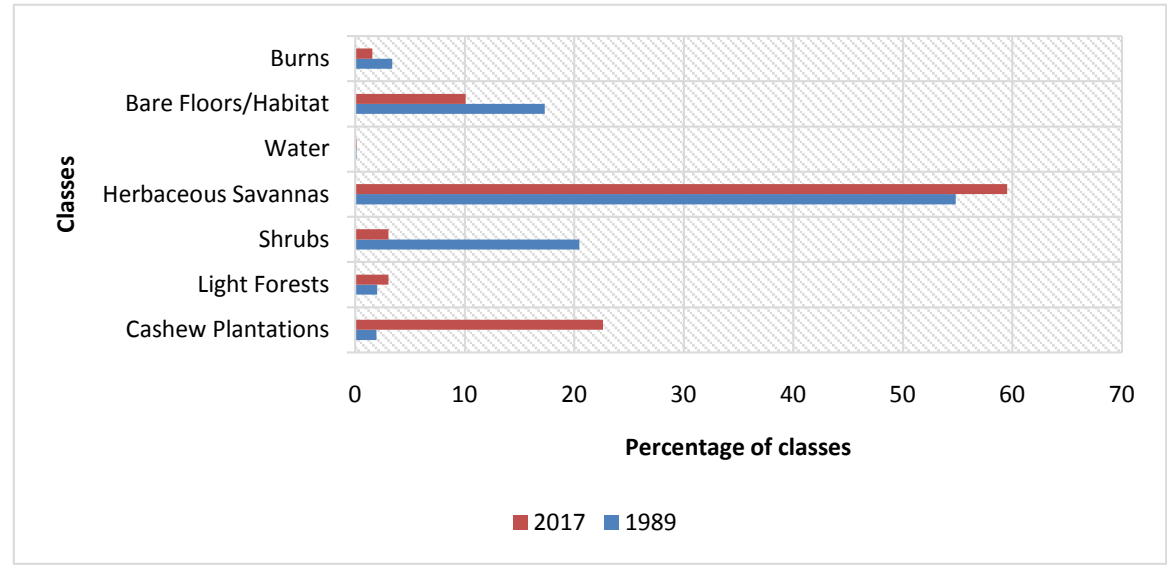

Figure 7. Changing in land use class areas from 1989 to 2017. 
Table 11. Land use class change rate between 1989 and 2017.

\begin{tabular}{ccc}
\hline Classes (ha) & $\mathrm{Gc}\left(\mathrm{km}^{2}\right)$ & $\mathrm{Gc}(\%)$ \\
\hline CP & 1365.36 & 20.68 \\
LF & 68.48 & 1.03 \\
S & -1150.68 & -17.42 \\
HS & 310.35 & 4.7 \\
W & 1.59 & 0.02 \\
BF/H & -476.67 & -7.21 \\
B & -118.43 & -1.79 \\
\hline
\end{tabular}

Table 12. Land use class change rate between 2000 and 2017.

\begin{tabular}{ccccccccc}
\hline Classes (ha) & CP & LF & S & HS & W & BF/H & B & Total \\
\hline CP & 70.47 & 11.02 & 6.56 & 488.23 & 0 & 246.6 & 19.71 & 1493.05 \\
LF & 1.66 & 73.59 & 0.80 & 25.85 & 0.01 & 3.8 & 14.67 & 200.47 \\
S & 5.58 & 18.81 & 1.57 & 11.72 & 0 & 2.02 & 4.87 & 200.79 \\
HS & 39.10 & 26.69 & 4.01 & 2728.65 & 0.10 & 559.44 & 173.64 & 3928.97 \\
W & 0.01 & 0.03 & 0 & 0.01 & 7.26 & 0.06 & 1.56 & 8.97 \\
BF/H & 9.78 & 0.43 & 0.45 & 289.44 & 0 & 315.87 & 4.38 & 665.38 \\
B & 1.01 & 1.36 & 0.09 & 74.46 & 0 & 14.54 & 3.91 & 104.41 \\
Total & 127.68 & 1.32 & 1351.47 & 3618.63 & 7.38 & 1142.06 & 222.83 & \\
\hline
\end{tabular}

\section{Discussion}

In this study, a spatial-temporal dynamic of LULC was assessed based on image classification and change detection method. The study highlights that, the overall accuracy of the image classifications is $96.16 \%$ for $1989,96.07 \%$ for 2000 and 92.83\% for 2017. Some confusion in the classification have been notice but not affect too much the results, the classification is considered acceptable when the overall precision is close to $80 \%$ [23] and [20]. This is consistent with the studies undertook by some author like [10] and [10], who respectively obtained global precisions of $96.2 \%, 95.03 \%, 94.8 \%, 87.17 \%$, and $82.13 \%$.

In this study, the most important confusions were observed firstly, between cashew culture classes and shrubs and then, between herbaceous savannas and the class of bare habitats and soils. This can be explained by the fact that these two classes share some of the same characteristics. The shrubs is being converted in light forest by shrubs from eight to fifteen metres high, just like a cashew tree (five to fifteen metres high) [6]. Also, cashew tree plantations are generally cultivated in savannas zones, which can make it difficult to discriminate between these two formations. As for confusion between the classes of herbaceous savannas and bare floors/habitat, it is due to the fact that herbaceous savannas are heterogeneous. Food crops, cocoa trees and agricultural clearing and areas used for food crops from the previous year after harvest (fallow) were find. The same 
observation were made by [19] in the study on monitoring land use dynamics using satellite imagery and geographic information systems: case of the regional water and forest directorate of Yamoussoukro (Côte d'Ivoire).

Image analysis and classification, revael that the land use/ land cover map of Niakaramadougou department has been dominated by agricultural activities, including an expansion of cashew culture between 1989 and 2017 from 2\% to $22.61 \%$, i.e. from $127.69 \mathrm{~km}^{2}$ to $1493.05 \mathrm{~km}^{2}$. the rapid growth of cashew culture areas was made to the expense of savanna formations. It could be explained by the increase in cashew nut prices from 1994 to 2000. The same conclusion was made by [24] who explain that cashew nuts were promoted in the 1950s by the agricultural services for their ecological services. They are drought resistant. Since 1990s it was less know by farmer. But when Asian cashew buyers came to prospect in northern Côte d'Ivoire from the 1990s to 2000, farmers valued the tree [25]. Thus, cashew plantations were created abondantly between 2001 and 2013 , a prolonged period in the price of seed cotton. While cotton prices remained lower during a long period, cashew nut prices knew two periods of high prices (1994-2000 and 2014-2017, and 2018) (Figure 9), which was the trigger.

Furthermore, massive cashew production could be justified by the return of people to their own villages. the decline in cocoa income, resulting from the fall in prices (Figure 8), and then the fall in yields due to cocoa diseases causing the destruction of some plantations. The drop of cocoa income, initially generated frustration and the return of migrants to their own villages to develop cashew nuts, and thus initiate crop diversification, in the cotton culture, and cocoa culture.

These results converge with those obtained by [26]. According to his study, the areas occupied by cashew cultivation in rural areas southwest of Comoé National Park increased from 11,743 hectares in 2002 to 29,872 hectares in 2014 (i.e. more than 160\%), while the surface area of forests (gallery forests and dense

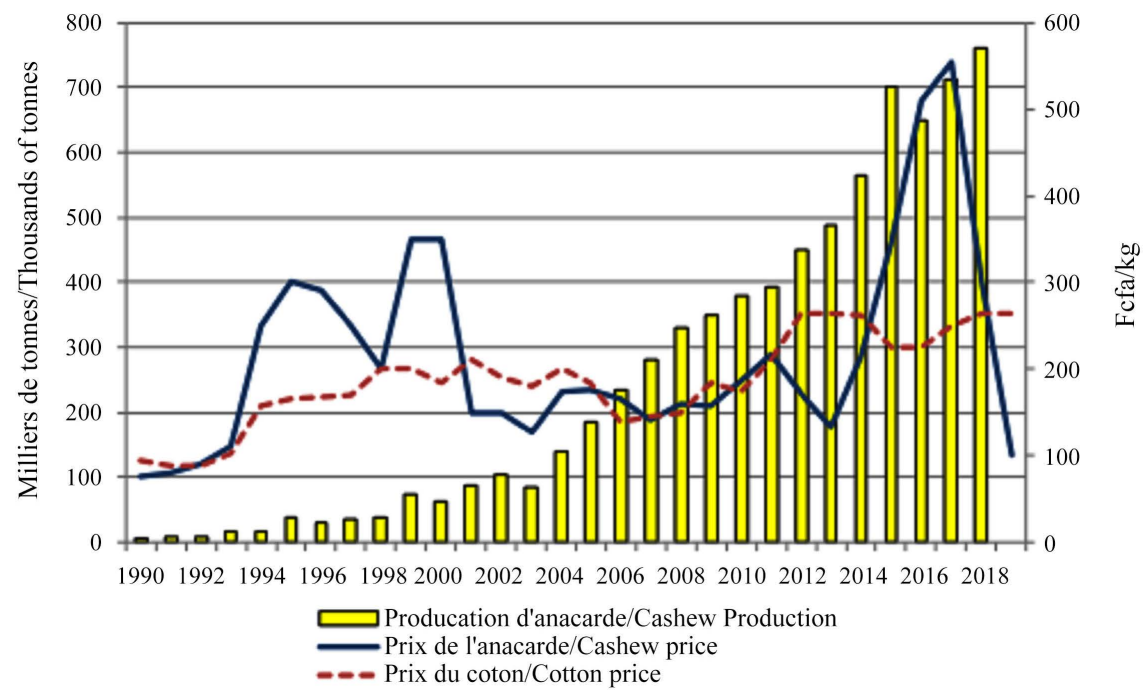

Figure 8. Current and constant prices of cocoa paid to producers from 1961 to 2008 [24]. 


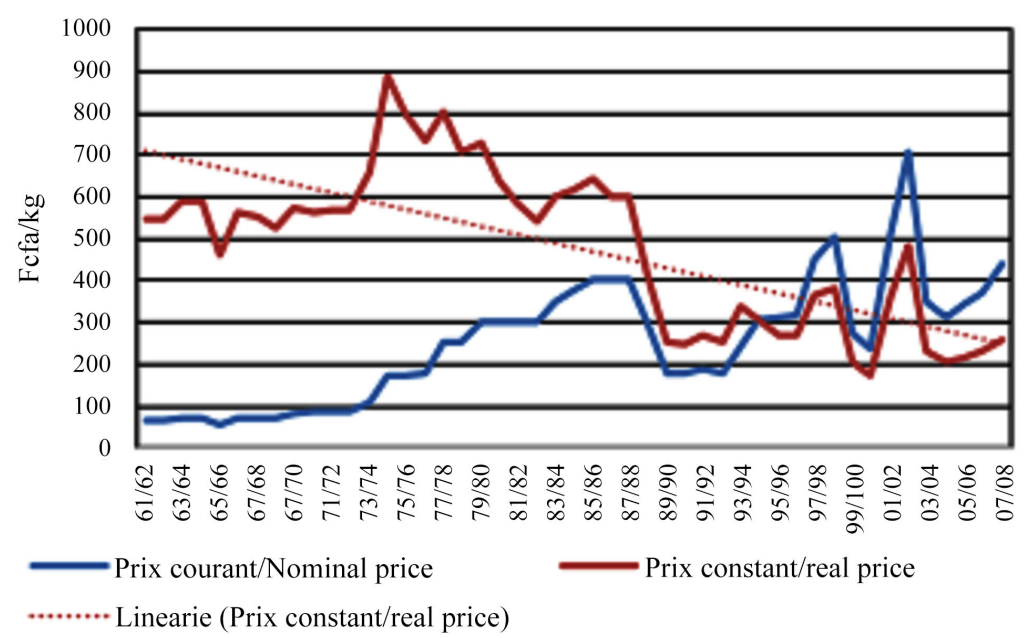

Figure 9. Current and constant prices of cocoa paid to producers from 1961 to 2008 [24].

dry forests) has fallen sharply, from 26,242 hectares in 2002 to 6133 hectares in 2014 (i.e. 76\%). The decrease in natural vegetation could have consequences on biodiversity. The destruction of these natural ecosystems is accompanied by a loss of biological diversity [27]. Animal and plant species linked to certain biotopes are directly threatened with extinction [28]. It is therefore important to make an inventory of the flora and vegetation of Côte d'Ivoire [29] in order to take appropriate and sustainable protection measures.

\section{Conclusion}

This study attempts to bring out the influence of cashew plantation on the natural environment from 1989 to 2017, using landsat image data. The study revealed that the natural environment of the Niakaramadougou department is undergoing major changes. The savannah formations have been strongly affected by this progression of the cashew trees in Côte d'Ivoire. The work showed that the dynamics of the landscape of the Niakaramadougou department are characterized by an increase in the surface area of the cashew trees. These surfaces, which were $127.69 \mathrm{~km}^{2}$ or $1.93 \%$ of the total surface area of the study area in 1989 , increased to $1493.05 \mathrm{~km}^{2}$ or $22.61 \%$ in 2017 . The savannah formations have lost $840.33 \mathrm{~km}^{2}$ or $12.26 \%$ of their original area. The few forest galleries recorded a slight increase of about $1 \%$. The rate of cashew plantations is changing is becoming worrying. We recommend further studies to assess its impact on other aspects of the environment

\section{Conflicts of Interest}

The authors declare no conflicts of interest regarding the publication of this paper.

\section{References}

[1] FAO (2018) Base des Données de la FAO 2002. http://www.fao.org/home/en/ 
[2] Rabany, C., Rullier, N. and Ricau, P. (2015) The African Cashew Sector in (2015): General Trends and Country Profiles. Analysis of Cashew Production, Processing and Trade in Africa, $30 \mathrm{p}$.

[3] FIRCA (2018) Impact Des Actions Menées Par La FIRCA Et Zones D’intervention Désagrégées Par Genre. Les Technologies Générées/Diffusées Par Le FIRCA Pour Le Compte De La Filière Anacarde, Abidjan, 8 p.

[4] Diallo, M., Manéré, O., Pièrre, R. and Cédric, R. (2015) Etude du marché de l'anacarde au mali et en afrique de l'ouest pour le projet "commercialisation et transformation de l'anacarde dans la région de sikasso", financé par la coopération espagnole et mis en œuvre par tragsa et le ministère de l'agriculture de la République du Mali, $60 \mathrm{p}$.

[5] Didier, C. (2001) La culture de l'anacardier. Fruitrop (ed. Française), 81, 2-4.

[6] Lacroix, E.J. (2003) Les anacardiers, les noix de cajou et la filière anacarde à Bassila et au Bénin. Projet restauration des ressources forestières de Bassila, Bassila, 75 p.

[7] RONGEAD (2013) Connaître et comprendre le marche international de l'anacarde. Document élaboré par RONGEAD à Partir de son expérience d'appui à la filière anacarde, notamment dans le cadre de la mise en œuvre du service d'information et de conseil, $48 \mathrm{p}$.

[8] N'djolosse, K., Badou, A., Bello, S., Maliki, R., Kpera, G., Nathalie, O. and Gaston, A.A. (2018) Formules d'engrais minéraux n.p.k. pour de meilleurs rendements en noix d'anacarde selon l'âge des plantations au Centre-Bénin et au Nord-Bénin, 12 p.

[9] Combres, J.C. and Eldin, M. (1972) Eléments généraux de climat in Atlas de Côte d'Ivoire, ORSTOM. Inst. Géo. Trop. Univers., Abidjan, A3a, 150 p.

[10] Doannio, J.M.C. (2003) Transmission du paludisme a kafine, un village de riziculture irriguée de côte d'ivoire et essai de lutte par utilisation des moustiquaires “olyset net " en zone de résistance de anophèles gambiae s. S. (giles, 1902) aux pyrethrinoides. Thèse de Doctorat, Université de Cocody, 2014 p.

[11] FAO (2017) Cartographie de la dynamique forestière de 1986 à 2015. FAO, 18 p.

[12] Sleimi, T. (2018) Étude du potentiel de l'imagerie historique landsat pour la délimitation des cotes des crues de référence: Cas de la rivière petite nation. Mémoire de Maitrise, Université du Québec, 77 p.

[13] Chander, G., Huang, C., Yang, L., Homer, C. and Larson, C. (2009) Developing Consistent Landsat Data Sets for Large Area Applications: The MRLC 2001 Protocol. IEEE Geoscience and Remote Sensing Letters, 6, 777-781. https://doi.org/10.1109/LGRS.2009.2025244

[14] Chavez Jr., P.S. (1988) An Improved Dark-Object Subtraction Technique for Correcting Atmospheric Scattering of Multispectral Data. Remote Sensing of Environment, 24, 459-479. https://doi.org/10.1016/0034-4257(88)90019-3

[15] Song, C., Woodcock, C.E., Seto, K.C., Lenney, M.P. and Macomber, S.A. (2001) Classification and Change Detection Using Landsat TM Data: When and How to Correct Atmospheric Effects? Remote Sensing of Environment, 75, 230-244. https://doi.org/10.1016/S0034-4257(00)00169-3

[16] Coulibaly, T.J.H. (2009) Répartition spatiale, gestion et exploitation des eaux souterraines: Cas du département de katiola, région des savanes de côte d'ivoire. Thèse de Doctorat, Université Paris Est, 141 p.

[17] Donnay, J.P. (2000). Les spatiocartes en composition colorée. Bulletin de la Société Géographique de Liège, 38, 43-61.

[18] Folohouncho, B.E. (2015) Utilisation de la télédetection et des SIG dans la gestion 
durable des aires protégées: Cas des forets classees de Dogo-Ketou au Bénin. RECTAS Obafemi Awolowo University Campus-Diplôme d'Etudes Supérieures Spécialisées (DESS), $59 \mathrm{p}$.

[19] Kouassi, K.J.L. (2013) Suivi de la dynamique de l'occupation du sol à l'aide de l'imagerie satellitaire et des systèmes d'informations géographiques: Cas de la direction régionale des eaux et forêts de yamoussoukro (cote d'ivoire). l'institut national polytechnique houphouët boigny de yamoussoukro. Mémoire de master à l'institut National Polytechnique Houphouët Boigny de Yamoussoukro, 52 p.

[20] Girard, M.C. and Girard, C.M. (1999) Traitement des données de télédétection. Dunod, Paris, $529 \mathrm{p}$.

[21] Schlaepfer, R. (2002) Analyse de la dynamique du paysage. Fiche d'enseignement 4.2, Laboratoire de Gestion des Ecosystèmes, Ecole Polytechnique de Lausanne, Suisse, $10 \mathrm{p}$.

[22] Sintondji, L., Agbossou, E. and Degnissode, B. (2013) Dynamique de dégradation des forêts galeries et comblement du cours d'eau agbado dans le département des collines au Bénin. International Journal of Biological and Chemical Sciences, 7, 1555-1567. https://doi.org/10.4314/ijbcs.v7i4.12

[23] Congalton, R.G. (1991) A Review of Assessing the Accuracy of Classifications of Remotely Sensed Data. Remote Sensing of Environment, 37, 35-46. https://doi.org/10.1016/0034-4257(91)90048-B

[24] François, R., Siaka, K. and Boniface, B. (2019) Le boom de l'anacarde en côte d'ivoire: Transition écologique et sociale des systèmes à base de coton et de cacao. cah. Agric, 28, 12. https://doi.org/10.1051/cagri/2019019

[25] Basset, J.T. (2009) Mobile Pastoralism on the Brink of Land Privatization in Northern Côte d'Ivoire. Geoforum, 40, 756-766.

http://www.sciencedirect.com/science/article/pii/S001618509000438 https://doi.org/10.1016/j.geoforum.2009.04.005

[26] Sangne, C.Y., Bamba, I., Kpangui, B.K., Kouakou, A.K. and Barima, Y.A.S. (2019) Emprise des champs d'anacarde sur les forêts et savanes en milieu paysan autour du parc national de Comoé. International Journal of Biological and Chemical Sciences, 13, 662-675. https://doi.org/10.4314/ijbcs.v13i2.8

[27] Teyssèdre, A. (2004) Vers une sixième grande crise d'extinctions? Biodiversité et changements globaux: Enjeux de société et défis pour la recherche. Ministère des Affaires Etrangères-ADPF, Paris, $36 \mathrm{p}$.

[28] Lavergne, S. (2004) Les espèces végétales rares ont-elles des caractéristiques écologiques et biologiques qui leur sont propres? Application à la conservation de la flore en Languedoc-Roussillon. Acta Botanica Gallica, 151, 327-331. https://doi.org/10.1080/12538078.2004.10515434

[29] Koffi, K.J., Kouassi, A.F., Yao, C.Y.A., Bakayoko, A., Ipou, I.J. and Bogaert, J. (2015) The Present State of Botanical Investigations in Côte d'Ivoire. Biodiversity Informatics, 10, 56-64. https://doi.org/10.17161/bi.v10i2.5007 